\title{
Procedural Aspect at Issues the Minor
}

\section{Antoneta Gjolena}

\author{
Eurepean University of Tirana; anagj@hotmail.it
}

\section{Doi:10.5901/ajis.2015.v4n3s1p331}

\begin{abstract}
In the criminal procedure code are provided provisions which are applicable in criminal proceedings against minors. Seen as of a special significance the pursuit of appropriate, given that the procedural aspect violates directly the fundamental right and freedoms of the individual, in this case those of minors. - The objective of this study will be an analysis of these provisions as well as be treated the comparative aspect with developed countries from which we can draw conclusions and give a recommendation in the case of any inadequancy of the provisions contained in the Criminal Procedure Code of the Republc of Albania at the handlingof case of juvenile in criminal proceedings.
\end{abstract}

Keywords: criminal procedure, juvenile legislation, fundamental rights and freedoms of the individual

\section{Introduction}

Protection of children's rights and freedoms constitutes one of the most important matters of the Albanian state, clearly expressed this in the constitution, criminal code, criminal procedure code and all the international conventions which have been ratified by the Albanian state and are mandatory to apply. Given the age of the child, his development of physical and mental health, which is still in the process of development, a child needs special protection not only from family but also from state institutions involved in the delivery of justice for minors. Procedural aspect has great significance since by the first moment they got detained until the judicial process after an improper procedure would violate fundamental rights and freedoms of the individual. Given the procedural Aspects that play a crucial role in the delivery of justice through this paper we will analyze the provisions, which are applicable to minors. The interest to tackle this subject, bore to me as a result of problems encountered in practice, linked with the implementation of jurisdiction and powers of the proceeding body investigating or judging cases of minors as subjects of criminal offenses. In carrying out this work, a special importance in this paper get exactly procedural aspects right from the moment of detention of minors, until the moment of judicial process. Since the Albanian Justice System for juvenile faces a diverse problem that can not be exhausted by no means onlby through a paper nevertheless, what I hope is to analyze some of the most prominent problems in the criminal proceedings.

\section{Detention of Minors}

Juvenile criminal proceedings includes the entirety of the procedural acts undertaken against a person from the moment of taking him as a defendant, until the taking of the final court decision against him. In the code of criminal procedure does not have a separate chapter on the treatment of juveniles under prosecution. Also in this code are not anticipated principles of criminal proceedings related to minors and not reflected explicitly, the principle of the best interest of the child. It is the Police that takes the first contact with the offender. Its task is to accompany the person to the police station in cases where there are reasons to believe that a person has committed an offense. Code of criminal procedure has not provided in chapter 111 of Title $\mathrm{V}$ of the code of criminal procedure in Articles 251-259. This chapter contains general procedural aspects of the conditions and procedures of implementation and arrest in flagrancy and detention to be applied in a general way, without exception for any particular categories, including minors. Arrest in flagrancy is carried out when exist the conditions of urgency and criteria set out in Article 251, while the detention applies in cases of danger to flee of the person suspected of committing a crime. (Islami\& Hoxha\& Panda, 2007, 338). In cases of arrest in flagrancy or detention the judicial police agents are required to observe some general rules which are valid for minors. (Xhafo, 2012.101) which are as follows :

- To Inform the detained or arrested person in a language understood by him, about the causes of the measure of the accusations made to him: 
- $\quad$ To inform the prosecutor of the place where the arrest or detention took place;

- To make known the right to choose and defense lawyer and to notify defender elected or appointed by the prosecutor;

- To make the arrested or the detainee available in the cells, in the fastest time;

- To guarantee the right to human treatment and respect of dignity. (AYC, Article 28.5)

In cases where the arrested or the detainee is a minor, also apply to some specific rules ;

- Promptly notify parents or guardian (CPC, article 255/4)

- Ensuring protection in the case of minors is compulsory (CPC, Article 49)

- By order of the prosecutor, keeping in custody in his apartment, or any other observed place . (CPC Article 255/3)

If we refer to foreign legislation we would notice that there is provided a whole special measures in cases of detention that are not reflected in our legislation. In Italy we have special court police sections for minors (DPR 22-9-1988 n.448, which states that In each prosecution's office of the Republic at the Tribunal for juveniles has been instituted a section of the judicial police, at which it is assigned a staff with specific attitude and preparation. (D.P.R. 22-9-1988.n.448 Article 5)

According to the code of criminal procedure in case when does not order the immediate release, the prosecutor within forty-eight hours of arrest or detention, requires evaluation of the measure at the court of the locality where the arrest or detention took place. (Article 258/1 CPC). Deprivation of liberty for more than 48 hours must be authorized by the court and made on the premises of an institution of deprivation of liberty, which is under the authority of the Ministry of Justice. (Leskoviku 2010, 43) Article 54 of the Constitution guarantees that "Children, young people, pregnant women and new mothers have the right to special protection by the State". Minors should be held in separated facilities from those of adults, in the case of a minor must be notified immediately prosecutor, family and defense lawyer. Once the person is arrested, he must be notified immediately and in detail about the accusation made against him, his rights, as well as to the possibility to notify his family and his relatives (article 31 of the constitution ). While according the CCP of Italy, judicial police officers in such cases are required to notify not only the prosecutor and the family but also juvenile services. (CPC of Italy Article 18) As can be seen of the Criminal Procedure Code of Italy, on the juveniles, brings a positive example with regard to the italian procedural aspects in cases of detention and arrest of minors. (Xhafo 2012, 103) Article 35 of criminal procedure code states that:

1. to the juvenile defendant is provided legal and psychological assistance, in all the stages of the proceedings, in the presence of parents, other persons required by the minor and accepted by the authority proceeding.

2. The proceeding body can perform actions and draft acts, which require the participation of a minor without the presence of persons indicated in paragraph 1 , only when this is in the interest of minors or when the delay can severely damage the proceeding, but always in the presence of the defense. (CPC Article 35). As it is expressed in the Convention on the Rights of the Child according to which is stated : To the child is given the opportunity to be heard in any judicial and administrative proceedings, that has to do with it, either directly or through a representative or an appropriate body, in accordance with the rules of procedure of the national legislation (Convention on the Rights of the Child, article 12 / b) So, this provision is very clear about the aid provided to minors. This provision of the law is very clear in terms of assistance provided to the minors, either lawyer assistance either participation of psychologists throughout the criminal proceedings. Another problem to which is faced the police it is that concerning the identification of the minor's age. Article 41 of the code of criminal procedure, states that::

1. At every state and stage of the proceedings, when there is reason to believe that the defendant is a juvenile, the procedure makes the necessary verifications and, where appropriate for the expertise.

2. When, after verifications and expertise are still doubts about the age of the defendant is presumed that he is a minor. (Article 41 of the code of criminal procedure).

Whereas according to the Italian criminal procedure code, in terms of uncertainty for the defendant's criminal age, it reads as follows

1. At every state and stage of the proceedings, when there is reason to believe that the defendant is a juvenile, the judicial authority transmits the data to juvenile court prosecutor.

However, abuse is so common as minors often feel afraid of police officers they refuse to show their age or other essential data such as a home address. In a study made by UNICEF says: We have found more than once police using violence against minors only to get this information in time. (UNICEF, 2005.32). So an issue of great importance during the police proceedings, is interrogation of minors 
International acts recommend to be proceeded with special care. (Dervish, 2014j, 3) . Police during interrogation must take account of not using violence on minors. It is prohibited the use of violence in all ways of its manifestations!, that it clearly expressed in Article 25 of the Albanian Constitution and in Article 3 of the Convention for the Protection of Human Rights and Fundamental Freedoms which states: Nobody should subjected to torture, cruel, inhuman and degrading treatment or punishment. (AYC Article 25). However, as already mentioned above it is regrettable to be said , but to the police police lack the ability of communication with the minor but not only. Another problem in police stations as well as detention facilities is the lack of a psychologist and a translator as a minor has the right to interrogated in his own language, as it is foreseen in the code of criminal procedure in Article 123 which states : A defendant who does not know the Albanian language has the right to free assistance of an interpreter to understand the charge and follow the actions he takes part. Through an interpreter he makes a written statement that does not recognize the Albanian language (CPC Article 123) an aspect that leaves much to be desired.

As a preliminary conclusion, what we can say is that during the police proceedings are observed a number of shortcomings, where often these children are interrogated in the same place with the adults, to them is been exercised force to get the desired information. So, despite the provisions in relation to minors are clear, there is still much to be done in order to be taken into account the highest interest of the child.

\section{Detention on Remand}

Detention must be authorized by a court. In the criminal procedure code states that : Detention can be given only when other measures would be inappropriate because of the danger of the offense and of the accused. The judges for juvenile in individual cases can take a decision to put a measure of custody for the minor, only if it finds that the measure of imposing a temporary detention facility can not be achieved the proper and adequate effect (Arifi, 2011, 112) .

Alternative "Security measures" Includes house arrest, deposition of a guarantee and the obligation to periodic presentation to the police or be subject to the obligation to remain within a certain geographical area (Leskoviku, 211,44). In the code of criminal procedure are foreseen the limits for the duration of detention. The maximum duration of detention is up to two years, but there may be a extension of up to three years; but this is special case depends on the nature, type and complexity of the offence, ie in cases of crimes punishable by not less than ten years or to life imprisonment. This applies both for adults as well as minors. When a juvenile is arrested and is awaiting his trial, prosecutor must inform the judge on the progress in preparing the case every two months. (Leskovik ,2010,44). If we refer to Italian legislation, it has established criteria and conditions that reflect international standards being implemented in the shortest time possible . In general detention applies only in cases of a high risk crime. (CPC Italian Article 23) .

In Law No. 42014 is stated that Juvenile detainees are treated respecting fundamental freedoms and their rights. Treatment is based on the best interests of the child, social integration, education and prevention of getting involeved into crime. The law on the enforcement of criminal law on the treatment of prisoners and detainees, keeping in custody of juvenile in special institutions or in special sections. Law no. 8328 dated 6.04.1998 Article 75 on the rights of detainees, it sais that : In institutions of pre-trial detention for minors is prohibited their keeping in room with adults or putting of minors girls in a room with minor guys. Female juveniles are put in separate rooms and sections, creating the possibility of special treatment. Juvenile girls are held under the supervision and care only of female staff. (Law No. 8328, dated 6.04.1998). Here there is a contradiction as on legislative aspect, the provisions are very clear about serving the sentence by juveniles but institutionally seen, this leaves to be desired as there is no special institutions for minors. In our legislation it is made very clear this part, but there are exceptional cases as it can be Serbia where the minor during his stay in custody can be left in a room with adults, but it can be only in special cases when the judge for juveniles decides, but he must always bear in mind for an adult who is in custody with a juvenile not to affect him in a negative, but only in positive way. (Arifi, 2011,112) .

As a preliminary conclusion we can say that despite the legal definition that the security measures, detention in prison should be used when all other measures are inadequate, in our practice there is a common implementation of its and an extension in duration of detention. For this purpose, should be made legal changes to the CPC by defining specific terms of detention for juveniles and specific criteria for the application of this measure.

\section{The Judicial Process}

In Albania there are no juvenile courts. In Article 13 of the Code of criminal procedure states that "The trial of minors is done by the respective sanctions established by the district courts, stipulated by decree of the President of Rebublic" 
(CPC Article 13) Creation of sections of juvenile courts in six judicial districts, where are located even the courts of appeal, was an important step in the improvement of criminal justice. Each section consists of One judge. Crimes punishable by a sentence of more than 10 years should be judged by a panel of Three judges (Leskoviku ,2010,45).

In Italy we have special courts for juveniles that are established base on law 1404 dated 20 July 1934. Juvenile courts were created as autonomous courts of other courts of criminal or civil, and specialized about the nature and state a minor child.( Arpinati,2012,19)

The judge for preliminary investigations it is a monocratic body, while the judge for the preliminary hearing it is a collegial body composed of One magistrate and Two lay people ( art 50 bis og)

The appeal court has a special section for juveniles, composed of three stipendiary magistrate and two experts (one man and one woman)( art. 58 paragraph 2 and Article 4 disp att proc min) .

This is a positive example not only of Italian legislation but also of many other countries in terms of rendering justice for minors.

Court hearings are public otherwise shall be held as not valid (Article 339 CCP) but in the case of minors, are made exceptions provided in article 340 code of criminal procedure, which states that 'The Court decided that judicial review or some his actions held behind closed doors when necessary during the questioning of juveniles. (CPC Article 340 (d). This is an exception to be made to the general rule in which hearings are held with the open doors but this is done in order not to expose the minor.

As we have said even above, to the minors it is provided the presence of a psychologist at any stage of the proceedings as the police proceedings in that court as well. With regard the interrogation of minors, Code of criminal procedure provides that, the questioning of a minor witnesses can be done by the chairman, over the claims and objections of the parties. The President may be assisted by a member of the minor or a specialist in the field of child education. When it is estimated that the direct question of minors does not harm his psychological state, the president orders questioning to be continued under the provisions of paragraphs 1 and 2. The order can be revoked during questioning. (Article $361 \mathrm{CCP}$ ).

These are rules that must be respected not only in the judicial process but also in the preliminary investigation by the prosecutor as well as by the judicial police officer. The latter when to interrogate a juvenile should be assisted by a family or by a psychologist. The interrogation of minors is investigative action particularly important, complex and with many features from the interrogation of persons over 18 years old (Spiro, 89, 57) This is because the minors because of their age have not yet reached proper maturity to understand the importance of the case. Judge before interrogating the juvenile should be informed better on education, family, his habits that might have affected the minor in giving a judgment as fair as possible.

Publication of the generalities of minors is prohibited, this provided for in the code of criminal procedure. Minimum guarantees for children in conflict with the law are explicitly provided for in the Convention on the Rights of the Children which states: The criminal procedures to be guided without delay by the competent, impartial and independent organ or a panel with a hearing in accordance with the law in the presence of legal or other appropriate assistance unless it is considered that it is not in the interest of the child, especially taking account the situation in which the child or his parents or guardians are found (CRC Article 406).

As mentioned above, the legislation is very clear as to the position of minors by treating it in the most humane possible and favoring the latter throughout the criminal prosecit but the real problem lies in institutional and professional terms since most of the actors involved in the delivery of justice for juveniles are not trained and specialized. Another problem encountered in this stage of the proceedings are delays in judicial proceedings.

\section{Conclusions}

Legislation for juveniles has taken into consideration legislative changes and improvements but not institutional.

Police stations continue to keqtratohen minors.

There is a time duration of detention of minors, therefore it is to be required a change in the Albanian legislation defining time limits of juvenile detention.

Juvenile criminal cases not always are judged by special judges for minors.

Delays in court cases have been observed. 


\section{Recommendations}

Be created a special criminal and procedural code for minors.

Be trained and specialized all the actors involved in the delivery of justice for minors, the officer of the judicial police, prosecutors, lawyers, judge.

Psychologist to be present in all phases of the procedure that although it is clearly defined in the legislation often there is lacking of his presence in every stage of the procedure.

Be made intervention in legislation including, constitution, criminal law, the law in relation to the special treatment for juveniles.

Be trained and awared of all persons who work with minors.

Avoid as much as possible the stay of juveniles in detention.

Be created special penitentiary institutions for juveniles.

Be established reformatory schools.

To avoid as much as possible measure of arrest to prison more often and apply alternatives to imprisonment .

\section{References}

Arifi, R.( 2011). Juvenile delinquency in the Republic of Serbia for the period 2004-2008

Arpinati, E.(2012). Minor to the first offenses: Genoa experience of the Service Educational Planning for minors.

Dervisha, Ma,A.(2015). Communication-media-police-accused / Victim, in initiating a criminal proceeding .

Islami, H, Hoxha, A, Panda, I (2007) . Commentary of the Criminal procedure code, published with the support of DANIDA and Soros. Tirana

The Criminal code of the Republic of Albania

Code of criminal procedure of Albania

Code of criminal procedure of Italy

Convention for the protection of human rights and fundamental freedoms. Tiran 2010

Convention on the Rights of the Child

Constitution of the Republic of Albania 11/28/1998

Leskoviku, M. (20010). The penitentiary system. Tirana

Law No. 8328, dated 6.04.998 "On the rights and treatment of inmates and detainees'.

Perozziello, V. (2009). The juvenile process. Rome.

Spiro, S.(1982). Tactics of interrogation/question of witnesses and juvenile defendants. Tirana

Save the children.(2012). Training manual for professionals working with Babies in the penitentiary system. Tirana

Unicef.(2005) state violence in Albania.Un alterntive raport to the united nations comitte against torture. Tirana and Geneva.

Peza,N. (1968). On the criminal liability of minors. Tirana.

Xhafo, J. (2012) A minor and criminal process. Tirana. Pegi 